\title{
Expansão da agricultura e sua vinculação com o processo de urbanização na Região Nordeste/Brasil (1990-2010)
}

Humberto Miranda. Universidade Estadual de Campinas, Campinas, Brasil.

RESUMO | O processo de urbanização brasileiro tem se modificado nos últimos vinte anos. Os estudos em economia regional têm apontado para a forte influência da expansão da agricultura de exportação em territórios de fronteira como um dos principais determinantes da nova dinâmica urbana no período 1990-2010. Utilizam-se dados estatísticos para, primeiro, descrever a expansão da agricultura na área do bioma do cerrado na Região Nordeste do Brasil e, segundo, para analisar os possíveis efeitos que ela teve sobre o processo de urbanização no período. A análise dos efeitos sobre a urbanização em decorrência da expansão da agricultura é consequência do crescimento do plantio da soja para exportação nas áreas adjacentes dos Estados da Bahia (oeste baiano), Maranhão (sul maranhense) e Piauí (sudoeste piauiense). Conclui-se que o padrão de urbanização na Região Nordeste caracteriza-se por uma dinâmica urbana periférica devido ao aprofundamento das heterogeneidades socioespacias em anos recentes.

PALAVRAS-CHAVE | urbanização, relação campo-cidade, economia regional

\begin{abstract}
The process of Brazilian urbanization has changed in the last twenty years. Studies in the regional economy have pointed to the strong influence of the expansion of export agriculture in areas of the border as a major determinant of the new urban dynamics in the period 1990-2008. Statistics are used to describe the expansion of agriculture in the area of Savannah in northeastern Brazil, and to examine the possible effects it had on the process of urbanization in the period. The analysis of the effects of urbanization due to the expansion of agriculture is a consequence of growth for soybean exports to adjacent areas of the provinces of Babia (western Bahia), Maranhão (south Maranhão) and Piaui (southern Piaui). We conclude that the pattern of urbanization in the Northeast is characterized by a dynamic urban peripheral consequence of deepening social and spatial heterogeneity in recent years.
\end{abstract}

KEY WORDS | urbanization, countryside-city relationship, regional economy. 


\section{Introdução}

O objetivo geral é discutir o processo de urbanização como efeito da expansão da fronteira agrícola. Quanto aos objetivos específicos, busca-se descrever como se deu a expansão da fronteira agrícola na área do bioma do cerrado na Região Nordeste do Brasil e analisar o caráter da urbanização em áreas não metropolitanas, no período 1990-2010. O processo de apropriação privada do território brasileiro deu o sentido à ocupação econômica do espaço rural como se fosse um vazio social e ecológico. A outra face da ocupação econômica do rural foi o grande incentivo ao viés estritamente urbano de sua ocupação populacional. Um verdadeiro desequilíbrio socioespacial.

O espaço rural brasileiro foi, desde a colonização do continente latino-americano, considerado como "algo vago" e inculto, desvalorizado social, cultural e ecologicamente. Além das contradições e conflitos oriundos da desigualdade no acesso à terra, promoveu-se a desigualdade no uso e no acesso a recursos e espaços naturais. Tais recursos naturais não devem ser vistos apenas como os objetos da Natureza a serviço da atividade econômica estritamente; eles são espaços e recursos regulados pela Natureza e desigualmente usados e acessados pelos agentes econômicos e pela população. No cerne desse uso-acesso desigual do território está o crescimento da exploração do solo pela agricultura de larga escala, voltada ao mercado externo.

Ao examinar a especificidade do caso brasileiro, pode-se perceber o mesmo caráter de ocupação territorial do capital em outros países latino-americanos. Cobos (1989 e 2008) discute a relação entre o agro e a urbanização na América Latina, seu crescimento urbano anárquico e as mudanças nos processos territoriais na nova fase de acumulação do capital, mas também "os pobres resultados do neoliberalismo" neste continente após os anos de 1990, especialmente por aumentar o nível de desigualdade e heterogeneidade territorial (urbano-regional) (Cobos, 2010). Este pesquisador é bastante claro no que diz respeito ao desafio à nossa cultura científica e política:

(...) debemos construir nuestra propia cultura científica y política para explicar nuestra realidad particular y confrontarla críticamente con la venida de fuera, del norte en particular; debemos construir las políticas territoriales para transformar nuestra realidad y resolver sus contradicciones, a partir de su explicación científica, los instrumentos disponibles, los intereses que defendemos y nuestras posiciones en el abanico político-ideológico." (Cobos, 2010, p. 19)

Deste ponto de vista, pode-se perceber o mesmo caráter de ocupação do espaço urbano na América Latina, ou seja, em que pesem as especificidades de cada formação nacional, tem-se a mesma problemática, a do subdesenvolvimento urbano, especialmente nas análises sobre as áreas metropolitanas. Contudo, seguindo o conselho de Cobos, precisamos entender as particularidades da urbanização subdesenvolvida na maneira como ela se projeta para além das áreas metropolitanas. Afinal, são nas áreas não metropolitanas onde o espaço urbano se entrelaça mais fortemente com o espaço rural nos países latino-americanos e manifesta cabalmente as implicações das desigualdades e heterogeneidades socioespaciais. 
Para o presente momento, optou-se pela análise do caso brasileiro por este sintetizar a problemática da urbanização periférica, devido a: sua extensão territorial de cerca de 8,5 milhões de $\mathrm{km}^{2}$, sua numerosa população rural de cerca de 29,8 milhões de habitantes, sua alta taxa de urbanização de $84,4 \%$ e seu considerável avanço na modernização de sua agricultura, sem que se tenha equacionado o problema da concentração da terra. Segundo dados recentes do Instituto Brasileiro de Geografia e Estatística (IBGE), entre 2000 e 2010, houve um aumento do nível de ruralização relativa $(\mathrm{RR})^{1}$ da população das Regiões Norte e Nordeste, cujas populações rurais somadas aumentaram de 58,6\% em 2000 para 61,9\% em 2010 seu tamanho em relação à população rural total do Brasil; já as populações rurais somadas das demais regiões (Centro-Oeste, Sudeste e Sul) diminuíram de 41,4\% em 2000 para 38,1\% em 2010 o tamanho das suas populações rurais em relação à população rural total do país, que, por suas dimensões, reúne os elementos necessários para o estudo do padrão de urbanização. Isso quer dizer que, apesar do país ter uma alta taxa de urbanização, uma de suas grandes regiões em particular, a Nordeste, continua a concentrar o maior volume de população rural em termos absolutos, cerca de 14,2 milhões de habitantes, e relativos, $47,8 \%$, ou praticamente a metade da população rural do país.

A hipótese defendida neste artigo é de que a articulação entre o urbano e o rural, à medida que se dá mais ou menos intensamente, altera o padrão de urbanização, tornando-o predominantemente dispersivo no que se refere ao caráter da rede urbana nas áreas de fronteira. A abertura externa da economia brasileira nos anos de 1990 forjou novos determinantes para o urbano, reiterando a expansão da fronteira agrícola/mineral, que não estaria voltada para atender exclusivamente aos objetivos de expansão interna do produto industrial, mas também e principalmente para atender aos imperativos do mercado mundial de commodities, com mais países consumidores (asiáticos) e com a prática de melhores níveis de preços. Nesse ínterim, os anos de 1990 e 2000 mostram, de um lado, os grandes centros urbanos se saturando (de gente e atividades) e as cidades médias crescendo vigorosamente e, de outro, novas centralidades urbanas voltando a ocorrer e pequenas cidades continuando a surgir intermitentemente nas áreas de expansão da fronteira agrícola.

$\mathrm{O}$ artigo compõe-se de três partes. Na primeira, apresenta-se a desconcentração produtiva e as mudanças advindas com a maior internacionalização das estruturas produtivas regionais, especialmente no que se refere ao peso setorial da agricultura a partir dos efeitos da expansão da fronteira agrícola. Na segunda, discutem-se os efeitos sobre a urbanização no Arco dos Cerrados da Região Nordeste do Brasil, chamando-se a atenção para os processos de dispersão urbana derivados de seus vínculos com o desempenho do setor agrícola. Na terceira e última parte, o referencial teórico toma como base as características da urbanização em áreas de expansão da fronteira agrícola, observando como ele vai refinando a divisão social do trabalho para além da separação tradicional campo-cidade ou rural-urbana e promovendo outros padrões de urbanização na periferia subdesenvolvida, diferentemente do que ocorreu nos países centrais.

1 Nível de ruralização relativa é o percentual da população rural da região em relação à população rural total do país. 


\section{Aspectos metodológicos}

A metodologia nortear-se-á pela caracterização dos fatores que explicitem a evolução das heterogeneidades socioespaciais, relacionando os efeitos da expansão da fronteira agrícola vinculados ao processo de urbanização para o período mais recente (19902010), ao desempenho do setor agrícola na porção do território aqui denominada de Arco dos Cerrados Nordestino (ACNE), que tem expandido sua área plantada nos últimos anos. A Região Norte passou de 34,7 mil hectares de área plantada com soja (em grãos) em 1990 para 562,7 mil hectares em 2010; a Região Nordeste passou de 376,8 mil hectares de área plantada com soja (em grãos) em 1990 para 1.857,1 mil hectares em 2010, segundo os dados da Produção Agrícola Municipal do IBGE. A Região Nordeste foi a que mais expandiu recentemente, sob a liderança dos Estados da Bahia, Piauí e Maranhão. As informações geradas baseiam-se em dados secundários referentes aos municípios plantadores de soja nas três unidades da federação (UF) supracitadas. Analisa-se, portanto, municípios plantadores de soja, situados em áreas não metropolitanas e com baixa densidade demográfica.

O Arco dos Cerrados Nordestino, nos termos deste artigo, contém municípios das Mesorregióes com menor densidade demográfica nos Estado da Bahia, Maranhão e Piauí. De acordo com os últimos dados do Censo Demográfico do IBGE (2010), a Mesorregião do Extremo Oeste Baiano possui uma população de 579,2 mil habitantes e uma densidade demográfica de $4,96 \mathrm{hab} / \mathrm{km}^{2}$, destacando-se os municípios de Barreiras, Correntina, Luís Eduardo Magalhães, São Desidério, Riachão das Neves e Formosa do Rio Preto, com mais de 50 mil hectares de área plantada de soja. A Mesorregião do Sul Maranhense possui uma população de 308, 4 mil habitantes e uma densidade demográfica de $4,57 \mathrm{hab} / \mathrm{km}^{2}$, destacando-se os municípios de Balsas e Tasso Fragoso, com mais de 50 mil hectares de área plantada de soja. E, finalmente, a Mesorregião do Sudoeste Piauiense possui uma população de 511,6 mil habitantes e uma densidade demográfica de $4,0 \mathrm{hab} / \mathrm{km}^{2}$, destacando-se o município de Uruçuí, com mais de 50 mil hectares de área plantada de soja.

O período de análise será 1990-2010. Serão considerados dois sub-períodos na análise, 1985-1995/6 e 1995-2005/6, para efeito de caracterização da estrutura fundiária nas diferentes áreas, através de definição de seus estratos, baseada nas informações dos dois últimos Censos Agropecuários, da Produção Agrícola Municipal e dos Censos Demográficos, incluindo o mais atual, de 2010. No período, daremos ênfase ao caráter mais prospectivo da análise, o que nos remeterá aos aspectos mais específicos dos efeitos da expansão da fronteira agrícola sobre a dinâmica urbana nordestina, durante o processo de desconcentração produtiva regional.

Para a análise dos aspectos relativos à urbanização nos municípios plantadores de soja na Região Nordeste do Brasil (Anexo, Figura 1), foram selecionados 49 municípios plantadores de soja, com áreas a partir de 1.000 hectares, sendo: 09 municípios plantadores na Bahia, 15 municípios plantadores no Piauí e 25 municípios plantadores no Maranhão (Anexo, Figuras 2, 3 e 4). A relação básica a ser analisada é entre o percentual da área plantada (AP) na cultura de soja versus a taxa 
de urbanização (TU) e a densidade demográfica (DD), chamada neste artigo de relação AP X TU X DD. A análise dessa relação é possível apenas em áreas nãometropolitanas, justamente por captar a interação entre os espaços rural e urbano e verificar em que medida nas áreas de expansão da fronteira agrícola as taxas de urbanização são mais modestas ou não.

\section{A dinâmica regional da agricultura brasileira: aspectos gerais}

A dinâmica regional brasileira apresentou ao longo de sua evolução a seguinte peculiaridade econômico-espacial: uma forte concentração industrial acompanhada de uma contínua expansão da fronteira agrícola. O que parecia para muitos uma dualidade ou contraste gerado pela especificidade do processo de desenvolvimento brasileiro, crescimento das cidades e "esvaziamento" do rural, hoje pode parecer uma regularidade da forma de inserção da economia brasileira no mundo globalizado, embora não necessariamente decorrente de um "esvaziamento" do rural, mas de sua maior importância para o urbano. O que parecia contraste torna-se complementaridade; o que era dualidade torna-se possibilidade de maior articulação rural-urbana ou perspectiva de maior integração territorial. O que estava definido como espaço residual, para além dos perímetros urbanos, hoje, o rural, parece mais "preencher" a dinâmica urbana do que ser seu pressuposto negativo, o não urbano. Um processo de "preenchimento" que pode ter seguido, como corolário, o curso da desconcentração produtiva regional após os anos de 1970.

No Brasil, a partir dos anos de 1990, a desconcentração produtiva regional e as mudanças advindas com a maior internacionalização das estruturas produtivas regionais passaram a requerer um maior peso setorial da agricultura, um dos mais importantes efeitos foi o prevalecimento das escalas seletivas do território em detrimento da escala nacional. Nesse processo, a dinâmica mais virtuosa da desconcentração produtiva, isto é, via mecanismos regionais de incentivo articulados ao desempenho da indústria nacional, passou a ser problemática ao privilegiar as especializações produtivas regionais e incentivar, livremente, seu acesso ao mercado internacional de commodities, sem que houvesse um conjunto de contrapartidas previamente determinado como, por exemplo, a imposição de limites à escala relativos à perpetração do trinômio apropriação-exploração-degradação do território.

Do ponto de vista da análise regional, os anos de 1990 marcariam o processo de desnacionalização da indústria e a adaptação gradual das economias regionais ao novo modelo de crescimento politicamente imposto desde o Plano Collor (1990) e aprofundado pelo Plano Real (1994), durante os governos dos presidentes Fernando Collor (1990-1992) e Fernando Henrique Cardoso (1994-2002) respectivamente. Com o desmonte da estrutura de planejamento do Estado e o esgotamento da sua capacidade financeira nesse período, as estratégias de inserção econômica regional tornaram-se mais competitivas e dependentes de mecanismos desarticuladores do desenvolvimento nacional. Um dos mais conhecidos desses mecanismos foi a concessão de subsídios fiscais via Imposto sobre Circulação de Mercadorias e 
Serviços (ICMS), cujo propósito maior era atrair investimentos (financeiros, imobiliários e locacionais) para as diferentes regióes. $\mathrm{O}$ acirramento da competição entre estados nesse processo de atração de investimentos privados ficou conhecido como "guerra fiscal" (Oliveira, 2002 e Monteiro Neto, 2005).

Segundo Cano (2008), as limitações estão imersas nos mecanismos da dinâmica regional após 1990: a manutenção do baixo crescimento da economia, desemprego, corte de crédito ao setor privado, a intensidade da exploração das bases de recursos naturais, a ampliação da "guerra fiscal" e o aumento da produção exportável com menor valor agregado são algumas das mais conhecidas. $\mathrm{O}$ processo de desconcentração produtiva regional ganha um novo caráter nos anos de 1990, ao tornar-se dinamicamente distinto, por causa do modelo de crescimento via inserção competitiva das economias periféricas. Esse processo muda de configuração a própria dinâmica urbano-regional e acentua o caráter itinerante da agricultura brasileira.

Salienta-se ainda que o período 2000-2010 aprofunda o processo de desconcentração engendrado na década de 1990, embora com algumas diferenças fundamentais: a reversão do déficit comercial em superávits crescentes a partir de 2002, como consequência da desvalorização cambial de 1999; a redução lenta e contínua das taxas de juros nominais a um patamar inferior aos $26,5 \%$ de 2003 ; o crescimento contínuo do PIB agropecuário no período pós-desvalorização cambial (1999-2004), conforme aponta Balsadi (2008); o chamado "efeito China", devido as suas altas e sucessivas taxas de crescimento econômico. Foram priorizadas as iniciativas de desenvolvimento local com maior inserção externa das regiões rurais, principalmente nos anos 2000, devido ao "efeito China", explicitando uma forte contradição entre a expansão da fronteira agropecuária e a exploração extensiva (espacialmente) e intensiva (ecologicamente) da base de recursos naturais, já que não resulta de ganhos de produtividade por hectare cultivado, mas da facilidade em manter a itinerância territorial como solução de conjunto para o crescimento da agricultura brasileira.

Nesse quadro mais amplo, torna-se relevante assinalar o caráter itinerante da agricultura brasileira, já apontado por Celso Furtado em alguns dos seus principais trabalhos (cf. Cano, 2002), e que permanece como uma característica estrutural interferente na dinâmica regional do país. A expansão da fronteira agrícola é seu veículo motor e se constitui num elemento estrutural, pois que dificulta a transição para um novo padrão produtivo nacional calcado na perspectiva da sustentabilidade ambiental do território, isto é, nas diversas frações inter e intra-regional do fenômeno da itinerância expressos no espaço, de modo extensivo e intensivo, incentivado economicamente pela exploração financeira e agromercantil. A chamada "integração competitiva" condicionou o processo de desconcentração produtiva regional, desarticulando-a de uma perspectiva nacional de desenvolvimento, e reforçou os mecanismos de incentivo estaduais à expansão da fronteira agrícola na periferia nacional.

Neste contexto mais geral, utilizando Delgado (2001) podemos discernir três períodos em que o tema agricultura e desenvolvimento regional adquiriram contornos mais precisos em face do que denominamos aqui de "itinerância territorial". 


\section{Primeiro período: pós-guerra a 1964}

Entre o pós-guerra e 1964, discutia-se o lugar do setor rural na economia e na sociedade em processo de franca industrialização, ora para que se ajustasse ao modelo seguido de substituição de importações, ora como promessa de um projeto explícito de política econômica. Nesse contexto, a emergência do tema da Reforma Agrária como "questão nacional" era disputado por três setores distintos: o Partido Comunista Brasileiro (PCB), os setores ditos progressistas da Igreja Católica e a Comissão Econômica para a América Latina (CEPAL). Vindo logo atrás, um quarto grupo, representavam os não-defensores da Reforma e de espectro ideológico oposto, cujo enfoque era industrialista e liberal-conservador.

Do lado dos setores politicamente progressistas da academia, destacam-se ainda as análises de Caio Prado Jr. (1960) e Ignácio Rangel (1961). O primeiro justifica a realização da Reforma Agrária brasileira naquele momento à possibilidade de elevar os padrões de vida da população rural (foco na inclusão socioeconômica). $\mathrm{O}$ segundo concentrou-se nos problemas da superprodução e escassez de produtos agrícolas (dificultando o comércio exterior) e da superpopulação rural (refletindo em desemprego urbano), fazendo com que o setor agrícola ora não liberasse mãode-obra em quantidade necessária para a expansão dos outros setores da economia, ora liberasse em excesso, rebaixando os salários. Um pouco mais tarde, viria à tona a problemática estrutural cepalina que foi expressa no caráter inelástico da oferta de alimentos vis-ád-vis as pressões da demanda urbano-industrial, como parte do diagnóstico do Plano Trienal (1963-1965), que justificava a necessidade de mudança tanto na estrutura fundiária quanto nas relações de trabalho no campo.

Completando o quadro evolutivo, chama atenção a mudança de mentalidade da Igreja Católica sobre a importância da Reforma Agrária. Este debate ganharia corpo com a criação da Conferência Nacional dos Bispos do Brasil (CNBB), nas décadas de 1950 e 1960, quando o episcopado constatou que a aplicação da doutrina da Igreja Católica contrastava com uma realidade agrária perversa. Foi posta em prática uma nova "doutrina social". Ocorre a denúncia da injustiça e da exclusão social, o que leva à igreja a obter importante influência política na época por ter inscrito na sua Doutrina Social o princípio da função social da propriedade, logo incorporado ao Estatuto da Terra (1964) e, mais tarde, à Constituição Federal (1988), atualmente em vigor.

Do lado dos setores politicamente conservadores, a proposição defendida por Delfim Netto considera refutável a tese cepalina da rigidez da oferta agrícola. Os economistas liberais defendiam a tese da "resposta funcional" da oferta agrícola às pressões da demanda, já que não consideravam a estrutura fundiária existente $\mathrm{e}$ nem as relações de trabalho no campo como questões econômicas relevantes. Para eles, não era uma questão política. Sendo assim, não havia razão para se realizar a reforma agrária, bastando que a agricultura cumprisse adequadamente suas funções via o estímulo da política agrícola, dentro do processo de desenvolvimento já em curso. Isto é, liberar mão-de-obra para a indústria, gerar oferta de alimentos, suprir 
a indústria de matérias-primas, elevar as exportações agrícolas e transferir renda real para o setor urbano.

\section{Segundo momento: 1965 a 1985}

O golpe militar de 1964, além de calar por meio da força o debate agrário mais amplo, sentenciou que o caminho proposto pelos economistas liberais era o que seria seguido. Caminho este que ficou conhecido mais tarde na voz dos economistas críticos pelas seguintes denominações: "modernização sem reforma", "modernização conservadora" ou "modernização dolorosa”. O Programa de Ação Econômica do Governo (PAEG), elaborado ente 1964-1966, pelos Ministros Roberto Campos (Planejamento) e Octávio Gouvêa de Bulhões (Fazenda), tinha como objetivo interpretar o desenvolvimento e formular uma política que eliminasse os estrangulamentos internos da economia que bloqueavam o crescimento. Para eles, a causa fundamental era a pressão inflacionária e somente a modernização do setor agropecuário surtiria efeito e não uma reforma. A Reforma só seria necessária se feita de modo pontual e, mesmo assim, onde a estrutura agrária, comprovadamente, gerasse ineficiência econômica, já que a expansão da agricultura dependia, segundo eles, de quatro fatores básicos: nível técnico da mão-de-obra; nível de mecanização; nível de utilização de adubos; e de uma estrutura agrária eficiente.

Tal modelo, além de ter imposto uma derrota política ao movimento social pela Reforma Agrária, ofereceu uma resposta política que priorizava a valorização do café e seu regime cambial favorável, que apressava a industrialização e a urbanização então em curso, diversificando e elevando consideravelmente as exportações agrícolas e agroindustriais. Estavam postas as condições objetivas para fortalecer o viés fortemente urbano no modelo de expansão da agricultura moderna ou do agribusisness brasileiro.

\section{Terceiro e último momento: o pós-1985}

No pós-1985, com o fim do regime militar e a abertura política, o debate em torno da questão agrária foi retomado como dilema político. $\mathrm{O}$ ambiente político interno passou a ser de radicalização da democracia, principalmente com as grandes manifestações da sociedade civil por eleições diretas para presidente da república e, mais tarde, com os debates acerca da elaboração da Nova Constituição Brasileira. No ambiente econômico externo, consolidava-se uma "nova ordem econômica mundial", com base em um crescente endividamento dos países latino-americanos e radicalização das doutrinas liberalizantes. Nesse novo contexto, estavam de um lado os movimentos sociais, que voltavam a atuar com toda força e de outro, aumentavam as restrições ao financiamento externo da economia brasileira, agravando a situação social e política.

Delgado (2001), porém, classifica os anos de 1980, no geral, como um período de transição. Para ele, o Brasil passou do período modernizante-conservador para o liberalizante-conservador, o qual tomaria realmente forma nos anos de 1990. 
Essa transição a que se refere representaria uma nova inflexão no debate agrário. As razões apontadas pelo autor são de que: o cenário econômico foi de relativa estagnação industrial nos anos de 1980 e prosseguiu assim nos anos de 1990; a agricultura que gerou altos saldos comerciais externos, especialmente na década de 1980, encontrou um clima inverso nos anos de 1990, quando as exportações em geral sofreram revés acentuado, particularmente com a entrada em vigor do Plano Real (1994-1995); o desmonte sucessivo do aparato estatal nos anos de 1980 e 1990, fez com que parte essencial das intervenções no setor agrícola, que vigoraram desde 1930 e foram recicladas pelo regime militar, deixassem de existir quase por completo; a falta de prioridade na política do desenvolvimento agrícola na agenda do Estado tornou-se fato consumado, motivada que foi, sobretudo, pela perda de impulso da própria industrialização; e a priorização do setor externo da economia no período recente foi, praticamente, a única política que restou do período modernizante-conservador.

O significado do debate agrário, de acordo com essa sintética periodização a partir de Delgado (2001), foi bastante simplificado no que se refere ao papel do setor agropecuário, o que amesquinhou o caráter nacional do desenvolvimento brasileiro. A modernização agropecuária foi substancialmente robustecida, com a diversificação e aumento da produção, alterando o padrão tecnológico do setor, mas, ao mesmo tempo, mantendo inalterada a heterogeneidade social. O pacto agrário-modernizante-conservador apoiou e defendeu o latifúndio na sua nova estrutura fiscal e financeira, fazendo com que todos os ingredientes políticos que precipitaram o debate mais amplo em torno da questão agrária ficassem em plano secundário, prontos para re-eclodir com mais força ainda nos anos de 1990.

Durante todo o ciclo de industrialização da economia brasileira, no período de 1930 a 1980, apesar de ter sido estabelecida uma rota clara guiada pelo modelo da substituição de importações ${ }^{2}$, o que se viu prevalecer foi um processo de urbanização como sinônimo de "cidades industriais", onde se criaria um universo de direitos e um processo de "ruralização" identificados com um universo de privaçóes. $\mathrm{O}$ rural passou a ser tratado de modo subsidiário dentro modelo de industrialização, como um setor, o agrícola, cumprindo um papel funcional dentro da expansão da indústria brasileira.

O padrão adotado teve duas funções precípuas: incentivou tanto a modernização do campo quanto a degradação ambiental do território nacional. Esta situação prosperou no apogeu da Revolução Verde no Brasil, nos anos de 1970; tornou-se um problema dramático a partir da década de 1980, com o fim dos subsídios agrícolas, revelando as conseqüências ambientalmente nefastas da mecanização agrícola, com crescente perda de recursos naturais (solos agricultáveis); se aprofundou nos anos de 1990 com o aumento da participação das commodities agrícolas na pauta exportadora, caracterizando uma exploração contínua da base de recursos naturais e vem intensificando-se ainda mais nos anos 2000, em direção às regióes rurais mais

2 Oriundo da Cepal, tal modelo foi concebido como um processo interno de desenvolvimento, estimulado por desequilíbrio externo, diversificação e crescimento do setor industrial. Ver Souza e Fonseca (2009). 
pobres e em áreas de transição ecológica entre a Região Nordeste (bioma Cerrado) e a Região Norte (bioma Amazônico) do país.

\section{Arco dos Cerrados Nordestino: especificidades da relação rural/urbano no Brasil}

O caso brasileiro permite entender os diferentes níveis de articulação entre o urbano e o rural, que ocorre mais ou menos intensamente, na alteração do padrão de urbanização, tornando-o predominantemente dispersivo ou concentrado no que se refere à rede urbana, dentro da tendência totalizante da relação entre capital e espaço. A escolha de uma unidade espaço específica, o Arco da Soja na Região Nordeste do Brasil, permite isolar as variáveis mais relevantes para a análise no estudo do fenômeno da expansão da fronteira agrícola como um traço estruturante da apropriação territorial capitalista brasileira.

O propósito desta seção não é o de elaborar cases ilustrativos das realidades das regiões brasileiras, mas de conceber o empírico com base numa estrutura teórica. Sendo assim, do ponto de vista teórico, sabemos que o capital penetra todas as relações e estruturas sociais quando atinge seu estágio mais desenvolvido. No momento atual, o estágio é de transição, isto é, de passagem da dominância capitalista num espaço determinado, o urbano-industrial, para uma dominância total do capital sobre o espaço. Em outras palavras, isso significa dizer que o movimento do capital no espaço, a fim de confiná-lo à lógica de acumulação e libertá-lo das raízes exclusivamente agrárias e estritamente urbanas, vai refinando a divisão social do trabalho para além da separação tradicional campo-cidade ou rural-urbana.

A área do Arco dos Cerrados na Região Nordeste do Brasil localiza-se no Bioma do Cerrado e compreende os Estados da Bahia (mesorregião do oeste baiano), Maranhão (mesorregião do sul maranhense) e Piauí (mesorregião do sudoeste piauiense) e direciona-se à Região Amazônica (Bioma Amazônico). O processo de expansão da fronteira agrícola é comandado pelo cultivo de grãos, especialmente a soja, para exportação. Nesse subespaço brasileiro, a relação entre o rural e o urbano ganha características próprias, marcadas por fortes heterogeneidades socioespaciais por causa de seus vínculos com o mercado exportador de grãos.

Observando-se o Gráfico 1, vê-se que o crescimento da área plantada com soja em grãos na Região Norte e Nordeste aumentou vertiginosamente nas três últimas décadas, 1990, 2000 e 2010. As duas regiões mais que dobraram a área plantada em relação ao Brasil na última década ${ }^{3}$. É um caso de rápida expansão da fronteira agrícola cujas consequências começam a ser avaliadas.

O aumento em 16 vezes da área plantada de 2000 em relação ao ano de 1990, na Região Norte, significou em termos absolutos passar de um patamar de 34,7 mil hectares para 562,7 mil hectares (aumento de 528 mil, aproximadamente), enquanto que na Região Nordeste o aumento de quase 05 vezes foi mais representativo em

3 Para facilitar a visualização do fenômeno, adota-se o índice 100 (cem) como representativo dos valores em hectares de área plantada do ano de 1990, que serve para confronto com os valores dos períodos seguintes. 
termos absolutos, passando de um patamar de 376,9 mil hectares para $1.857,1 \mathrm{mil}$ hectares (aumento de 1.480 mil, aproximadamente). As regióes com agricultura já mecanizada desde as décadas de 1970 e 1980, com relação apenas à área plantada com soja em grãos, as Regiões Sul e Centro-Oeste, partiram de patamares bem superiores em 1990, cerca de 6.159 mil hectares e 3.894 mil hectares e alcançaram 8.942 e 10.460 mil hectares em 2000, respectivamente. $O$ índice apresentado no gráfico acima chama a atenção para o crescimento expressivo da área plantada com soja em grãos naquelas duas regiões, que obtiveram taxas de urbanização praticamente iguais, $73,5 \%$ no Norte e $73,1 \%$ no Nordeste.

GRÁFICO 1 | Índice de Crescimento da área plantada com soja no Brasil e em suas Grandes Regiões $(1990=100)$

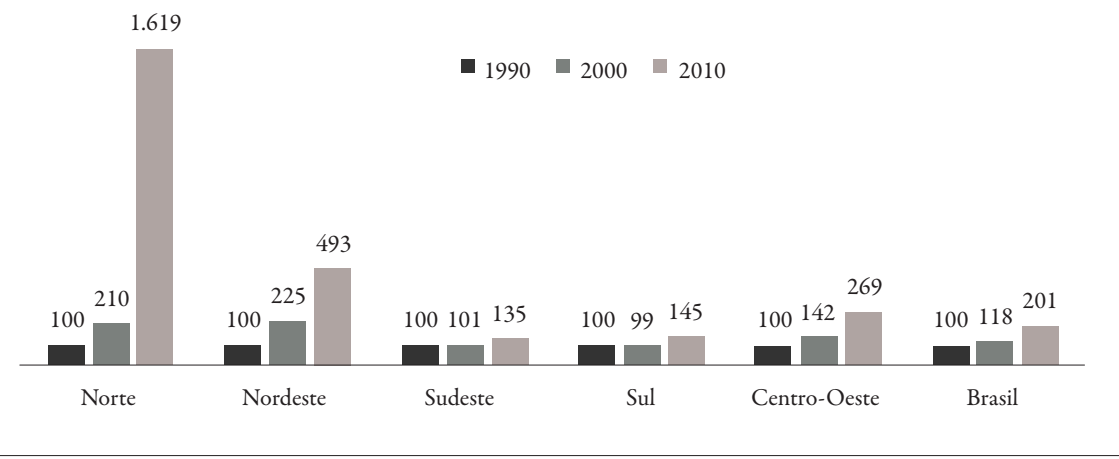

Fonte PAM/IBGE (2010) - ELABORADo PELAO AUtor.

A Tabela 1 a seguir mostra que as regiões da grande fronteira de expansão da agropecuária e mineral no Brasil - Centro-Oeste, Nordeste e Norte-, por diversos motivos, foram as que mais incrementaram suas taxas de crescimento da população urbana. Observa-se que a taxa de crescimento geométrico anual da população urbana na Região Nordeste, para os quatro períodos considerados, foi inferior ao do Brasil no $1^{\circ}$ período (1980/1970), 4,10\% a.a. vis-à-vis 4,44\% a.a., todavia, foi superior nos demais: $3,55 \%$ a.a. vis-á-vis $2,97 \%$ a.a. no $2^{\circ}$ período (1991/1980); $2,77 \%$ a.a. $v i s-\dot{a}$-vis $2,45 \%$ a.a. no $3^{\circ}$ período (2000/1991); e 1,65\% a.a. vis-á-vis $1,55 \%$ a.a. no $4^{\circ}$ período (2010/2000). No caso da Região Centro-Oeste, esta cumpriu já nos anos de 1970 seu papel de fronteira de expansão da agricultura comercial e mecanizada como hinterlândia da região mais industrializada, a Sudeste. Quanto à Região Norte, seu crescimento populacional se deve aos investimentos nos grandes projetos de mineração (Complexo Ferrífero de Carajás) e de hidroenergia (hidrelétricas), que geralmente provocam fortes fluxos migratórios de mão-de-obra barata. O caso da Região Nordeste, por sua vez, tem seu crescimento populacional relativo comandado por investimentos mais diversificados, seja na agricultura de exportação, especialmente os complexos da soja, gado e minérios, 
seja no setor de insumos básicos (investimentos vinculados ao processo de industrialização) concentrados em suas regiões metropolitanas. Nas Regiões Sudeste e Sul, com o processo de industrialização já consolidado, as taxas de crescimento geométrico se estabilizaram em patamares semelhantes à nacional, apresentando maior concentração e adensamento populacional.

TABELA 1 | Taxa de crescimento geométrico da população urbana residente no Brasil, por Grande Região

\begin{tabular}{|c|c|c|c|c|c|}
\hline \multicolumn{2}{|c|}{ UNIDADE ESPACIAL } & $1980 / 1970$ & $1991 / 1980$ & $2000 / 1991$ & $2010 / 2000$ \\
\hline \multirow[t]{5}{*}{ REGIÕES } & Nordeste & 4,10 & 3,55 & 2,77 & 1,65 \\
\hline & Norte & 6,44 & 6,26 & 4,78 & 2,61 \\
\hline & Sudeste & 3,99 & 2,34 & 1,92 & 1,31 \\
\hline & Sul & 4,98 & 2,98 & 2,41 & 1,36 \\
\hline & Centro-Oeste & 7,69 & 3,74 & 3,11 & 2,15 \\
\hline \multicolumn{2}{|c|}{ Brasil } & 4,44 & 2,97 & 2,45 & 1,55 \\
\hline
\end{tabular}

FONTE IBGE (CENSOS DEMOGRÁficos, VÁRIOS ANOS) - ELABORAÇÃo PRÓPRIA.

O crescimento do número de cidades associado ao ritmo de crescimento da população das cidades nos três estados selecionados na Região Nordeste - Bahia, Piauí e Maranhão - , de acordo com os últimos três censos populacionais, 1991, 2000 e 2010, apresenta padrões diversos. É necessário analisar cada classe de maneira independente em cada um dos estados, a fim de notar mudanças mais ou menos significativas no que tange ao processo de urbanização. Considera-se como "Classe Inferior", em que predominam as pequenas cidades, a classe de população até 20 mil habitantes; como "Classe Intermediária", em que predominam as cidades médias, a classe de população entre 20 mil e 50 mil habitantes; e como "Classe Superior", em que predominam as cidades grandes, a classe de população acima de 50 mil habitantes. Alerta-se que esta classificação é limitada à análise de áreas não metropolitanas e que, portanto, se busca destacar mais a quantidades de cidades em cada classe, a sua dispersão territorial, e não apenas a concentração de população nas cidades maiores.

No Estado da Bahia, conforme o Gráfico 2, a diminuição do número de cidades na classe até 20 mil habitantes no último período (2000-2010) é expressiva, cerca de 88 cidades mudaram de patamar populacional.

Houve neste estado um incremento na classe entre 20 mil e 50 mil habitantes no período 1991-2000, surgindo mais 24 cidades nesta classe de população e mais 09 cidades na classe acima de 50 mil habitantes. O que se vê retratado no Gráfico 2 é um caso de redução do quadro de dispersão urbana em favor das cidades nas classes de população intermediária e superior. São 24 cidades situadas na classe acima de 50 mil habitantes, com aproximadamente $60,0 \%$ da população total (5,62 mil- 
hões de habitantes), em 2010. A mudança de classe das pequenas para médias e para as grandes cidades é mais característica. Há redução do número de pequenas cidades acompanhando o crescimento mais expressivo do número de médias e grandes cidades, sendo mais distribuído entre as classes o contingente de população urbana.

GRÁFICO 2 | Bahia: número de cidades, segundo classes de população

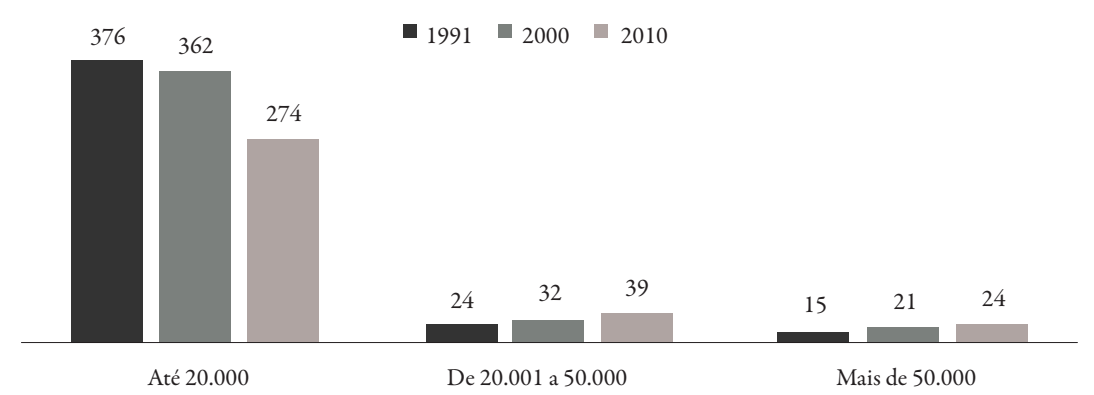

Fonte PAM/IBGE (2010) - ELABORADo PELAO AUTOR.

GRÁFICO 3 | Piauí: número de cidades, segundo classes de população

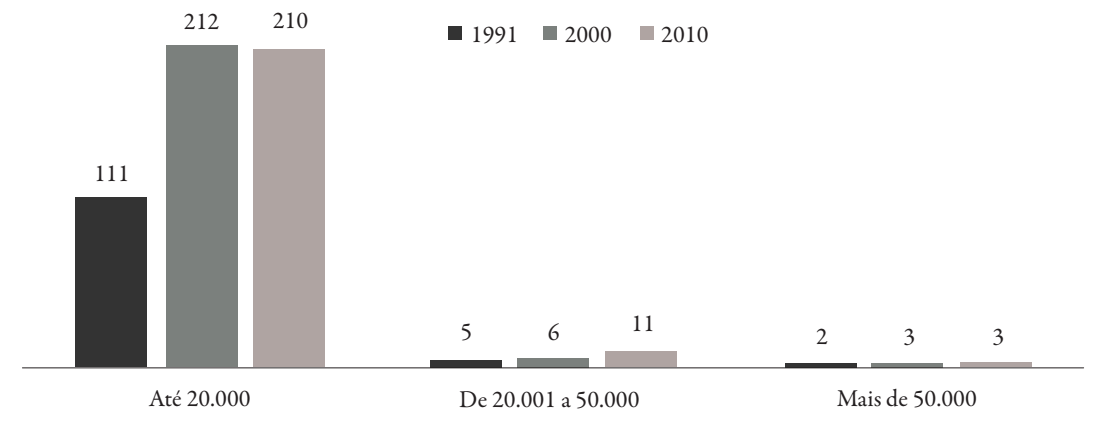

FONTE PAM/IBGE (2010) - ELABORADo PELAO AUTOR.

No Estado do Piauí, Gráfico 3, o crescimento do número de cidades na classe de até 20 mil habitantes é significativo. Uma nuvem de pequenas cidades surgiu (210 cidades) já no ano 2000, mas quase metade da população total do estado, cerca de $47,0 \%$ ou 963,3 mil habitantes, está concentrada em apenas três cidades na classe de cidades com mais de 50 mil habitantes. Não houve uma troca de classes acentuada entre as cidades, apenas marginalmente, o que, no caso do Piauí, mostra que a concentração da população urbana é mais intensa ainda na classe de cidades acima 
de 50 mil habitantes. A mudança de classe das pequenas para médias cidades não é expressiva e está estagnado o crescimento das cidades acima de 50 mil habitantes no Piauí. Ou seja, há grande número de pequenas cidades e forte concentração de população urbana em poucas cidades.

GRÁFICO 4 | Maranhão: número de cidades, segundo classes de população

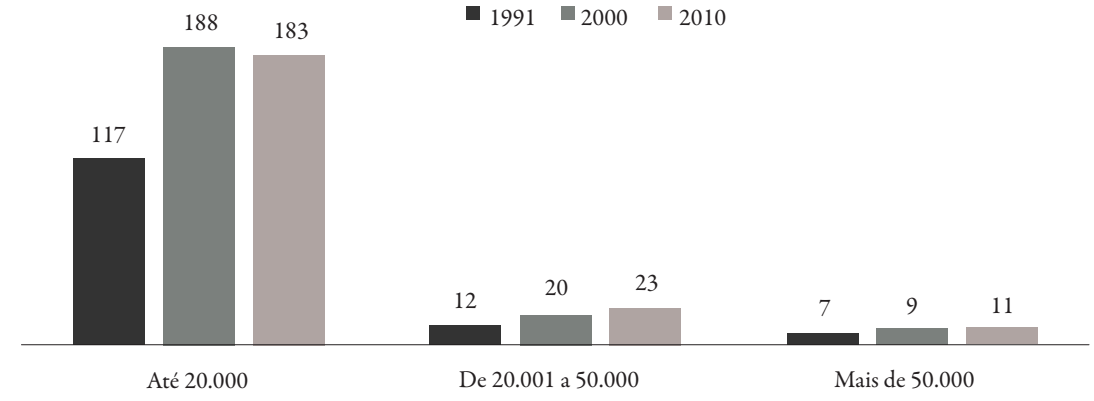

FONTE PAM/IBGE (2010) - ELABORADO PELAO AUTOR.

No Estado do Maranhão, Gráfico 4, diferentemente dos outros dois, verifica-se tanto um crescimento de cidades até 20 mil habitantes quanto um crescimento mais expressivo das cidades situadas na classe intermediária (de 20 mil a 50 mil habitantes) e um crescimento menos expressivo na classe acima de 50 mil habitantes. Entretanto, na classe acima de 50 mil habitantes, o contingente populacional, cerca de $47,7 \%$ ou 1.933,8 mil habitantes, está concentrada em 11 cidades, dentro da classe com mais de 50 mil habitantes em 2010. A mudança de classe das pequenas para médias cidades não foi expressiva no Maranhão, mas houve um crescimento importante das cidades na classe intermediária e um crescimento mais modesto na classe acima de 50 mil habitantes. A migração de algumas cidades entre as duas últimas classes, a intermediária e a superior, parece ser mais característica neste estado, já que não houve modificação substancial da classe inferior para a intermediária nos dois últimos Censos, 2000 e 2010.

O último Censo populacional brasileiro, divulgado no ano de 2011 pelo IBGE, mostra que as populações urbanas dos três estados estão concentradas na classe de cidades acima de 50 mil habitantes, mas é na Bahia que a população urbana concentra-se mais na classe superior que nas demais, a intermediária e a inferior, em termos populacionais, como mostra o Gráfico 5. Nos demais estados, Piauí e Maranhão, a somatória das populações urbanas das classes intermediária e inferior supera o da classe superior. Tem-se, assim, um estado, a Bahia, com maior concentração da população urbana, enquanto os outros dois, Piauí e Maranhão, permanecem com tendência à dispersão territorial de suas populações nas classes de população urbana intermediária e, principalmente, na inferior (até 20 mil habitantes), embora a Bahia continue, em termos absolutos, com maior número de pequenas cidades que Piauí e Maranhão. 
GRÁfico 5 | Bahia, Piauí e Maranhão: total da população das cidades, segundo classes de população

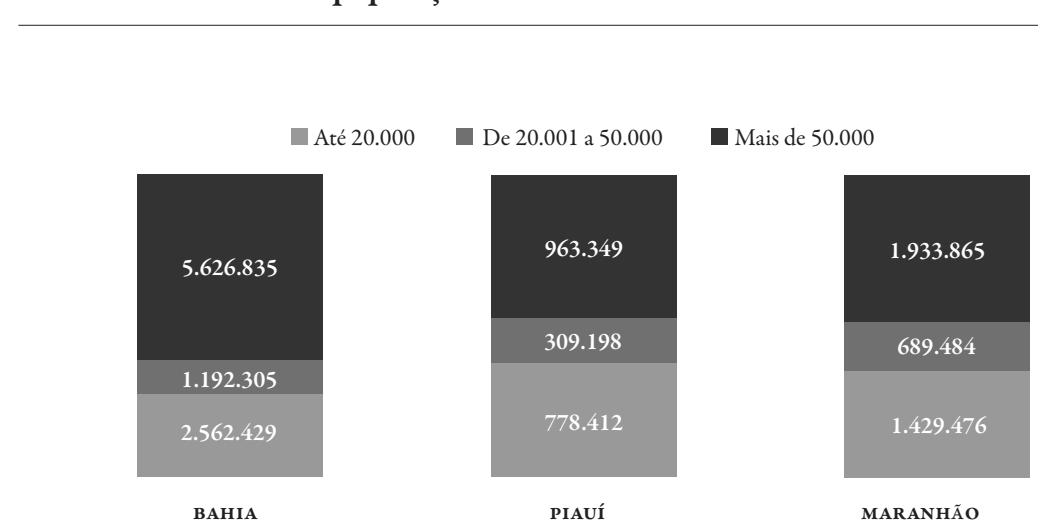

Fonte PAM/IBGE (2010) - Elaborado PElao AUtor.

As características acima referentes ao número de cidades por classe de população urbana e a população urbana por classe de tamanho são bastante gerais. Segundo os dados acima, na Região Nordeste, a urbanização ainda avança com ritmo próprio e em três de seus estados aqui analisados, o processo urbano avança de forma diferenciada. Como entender o que acontece nessa região e nos seus três estados, fugindo de certas uniformizações interpretativas do processo de urbanização? Que elemento comum estaria influenciando ou resultando em efeitos sobre o processo de urbanização nesses três estados?

Propõe-se relacionar tais características ao da área plantada (AP) com soja em grãos na região do Cerrado Nordestino. Com isso, especificam-se os municípios que fazem parte da área de expansão agrícola e o nível de dispersão das cidades. Como podemos perceber na Tabela 2, a área plantada total da soja em grãos na Região Nordeste e aquela correspondeste aos três estados do Nordeste aqui analisados. Esta área plantada, ressalvando os municípios com área plantada inferior a mil hectares, representa cerca de $99 \%$ da área plantada total de soja em grãos na região.

A AP Total distribui-se pelos três estados do Nordeste, ficando, aproximadamente, $57,0 \%$ da AP no estado da Bahia, 25,0\% no Maranhão e 17,0\% no Piauí. Considerando apenas os 49 municípios maiores plantadores, obtém-se uma AP Específica que concentra praticamente toda AP Total. Então, a intenção é verificar como a urbanização se manifesta nesta zona de expansão agrícola em particular. Chama atenção o fato de a expansão da fronteira agrícola da soja ter ocorrido no estado do Piauí nos últimos 10 anos, com sua AP crescendo 24\%, desde o ano de 2000 até o ano de 2009. Cabe informar que a Bahia é o estado que inicia essa expansão, vindo em seguida o Maranhão e o Piauí. A seguir, juntamos as informações de área plantada, urbanização e densidade demográfica desta área específica no cerrado nordestino. 
tabela 2 | Crescimento da Área Plantada de Soja em Grãos, segundo a região, os estados nordestinos e os municípios do $\mathrm{ACNE}^{*}$

\begin{tabular}{|c|c|c|c|}
\hline UNIDADE ESPACIAL & $\begin{array}{c}\text { ÁREA PLANTADA } \\
(\mathrm{HA})\end{array}$ & $\begin{array}{c}\text { ÁREA PLANTADA } \\
(\%)\end{array}$ & $\begin{array}{c}\text { \% CRESC. DA A. } \\
\text { PLANT. }(2009 / 2000)\end{array}$ \\
\hline Região Nordeste & 1.638 .637 & $100,0 \%$ & 7,61 \\
\hline Estado do Maranhão (MA) & 409.402 & $25,0 \%$ & 9,65 \\
\hline Estado do Piauí (PI) & 277.272 & $16,9 \%$ & 24,00 \\
\hline Estado da Bahia (BA) & 950.920 & $58,0 \%$ & 4,71 \\
\hline $\mathrm{BA}+\mathrm{MA}+\mathrm{PI}$ & 1.637 .594 & $99,9 \%$ & 7,60 \\
\hline Municípios do ACNE* & 1.620 .823 & $98,9 \%$ & 7,50 \\
\hline
\end{tabular}

Fonte IBGE (Produção Agrícola Municipal, 2009) - ElaboraÇão própria.

* Arco do Cerrado Nordestino: 49 dos Municípios do Nordeste com área plantada com Soja em grãos, a parTiR de 1000 HeCTARES.

A Tabela 3 apresenta os dados dos estados já contendo o número de municípios que corresponde à AP Específica que denominamos de Arco do Cerrado Nordestino (ACNE), considerando a relação entre área plantada (AP), taxa de urbanização (TU) e densidade demográfica (DD). Verifica-se que a Bahia tem o menor número de municípios dentro do ACNE, com 09, o Maranhão é o que tem o maior número, 25, e o Piauí fica numa posição intermediária com 15 municípios.

TABEla 3 | Estados Plantadores de Soja no Nordeste: taxa de urbanização, população urbana e número de municípios em 2010.

\begin{tabular}{|c|c|c|c|c|c|c|}
\hline UF & $\begin{array}{c}\text { NRO } \\
\text { MUNICÍPIOS }\end{array}$ & $\mathrm{AP}(\mathrm{HA})$ & AP (\%) & $\begin{array}{c}\text { POPULAÇÃO } \\
\text { URBANA } \\
\text { (HABITANTES) }\end{array}$ & $\mathrm{TU}(\%)$ & $\begin{array}{c}\text { DD } \\
\text { (HABITANTES/ } \\
\left.\mathrm{KM}^{2}\right)\end{array}$ \\
\hline BAHIA & 9 & 937.920 & 57,9 & 237.046 & 66,7 & 4,6 \\
\hline MARANHÃO & 25 & 406.481 & 25,1 & 330.675 & 59,1 & 6,0 \\
\hline PIAUÍ & 15 & 276.422 & 17,1 & 74.337 & 61,0 & 2,4 \\
\hline TOTAIS & 49 & 1.620 .823 & 100,0 & 642.058 & 61,9 & 4,7 \\
\hline
\end{tabular}

fonte IBge (Censo Demográfico e Produção Agrícola Municiapa) - eleboração própria. nota AP (Área Platada), TU (Taxa de Urbanização) e DD (Desidade Demográfica). 
Verifica-se que a Bahia tem o menor número de municípios dentro do ACNE, com 09 e quase $58 \%$ de AP com soja, o Maranhão é o que tem o maior número, 25 municípios e 25\% de AP, e o Piauí fica numa posição intermediária com 15 municípios e $17 \%$ de AP. A densidade demográfica é inferida a 10 habitantes por quilômetro quadrado para a ACNE em seu conjunto e em termos parciais por estado, o que levaria a supor que se trata de uma área rural típica. Todavia, ao se conhecer a taxa de urbanização da ACNE e as taxas parciais em cada um dos três estados, percebese que são superiores a $50 \%$, com destaque para a Bahia, que possui quase $67 \%$ de taxa de urbanização. Ou seja, há uma concentração razoável de população urbana nos municípios da ACNE. A expansão da fronteira agrícola incentiva também uma urbanização prematura, às vezes, mais acentuada que em grandes centros urbanos, cujo processo de urbanização está mais consolidado. Há de fato contradição entre o crescimento da taxa de urbanização em áreas de expansão da fronteira agrícola? Podemos chamar essas áreas ainda de rurais?

A hipótese explorada neste artigo é que a expansão da fronteira agrícola na região do cerrado nordestino estaria produzindo efeitos sobre o processo de urbanização, ainda que parcialmente, mas de forma relevante. Para verificar esta hipótese, ainda que de maneira preliminar, utilizam-se os dados da Tabela 04. A tabela traz um conjunto de informações relacionando variáveis rurais (em termos de área agrícola plantada e densidade demográfica baixa) e urbanas (taxa de urbanização). Cabe esclarecer, antes de tudo, que os dados de área plantada dos 49 municípios que compõem o subespaço denominado de Arco da Soja no Cerrado Nordestino foram agrupados em estratos de área. Isso dá uma dimensão atual da área plantada com soja (grãos) e seu peso percentual. Os dados da população total dos municípios são de 2010 e a taxa de urbanização foi extraída com base no último Censo Demográfico (2010), permitindo ter uma dimensão da população total atual e do grau de urbanização dos municípios em cada estrato de área plantada. Isso possibilita um entendimento melhor do processo de urbanização em áreas de expansão agropecuária, ainda que de forma preliminar. A intenção, entretanto, é explorar os dados mais recentes de forma independente para o conjunto dos municípios considerados em cada estrato de área e analisar a relação entre o estrato da área plantada, a taxa de urbanização e densidade demográfica correspondente do agrupamento de municípios situado em cada estrato, no subespaço regional denominado de Arco do Cerrado Nordestino.

Os dado da Tabela 04 consideram a taxa de urbanização, área plantada e densidade demográfica por estrato de área dos 49 municípios do ACNE. O estrato de área plantada com soja até 10 mil hectares é o que contem maior número de municípios (25), maior contingente de população total (42,8\%), maior densidade demográfica $\left(7,1 \mathrm{hab} / \mathrm{km}^{2}\right)$ em relação ao total do $\operatorname{ACNE}\left(4,6 \mathrm{hab} / \mathrm{km}^{2}\right)$, mas tem a menor área plantada e sua taxa de urbanização é igual ou levemente superior a 50\%. No extremo oposto, no estrato de mais de 100 mil hectares de área plantada, figuram 06 municípios, com o segundo maior contingente de população total (34,9\%), com a segunda maior densidade demográfica $\left(5,1 \mathrm{hab} / \mathrm{km}^{2}\right)$ em relação ao total do ACNE (4,6 hab/ $\mathrm{km}^{2}$ ), mas tem a maior área plantada e sua taxa de urbanização é a mais alta, de 79,0\%. 
TABela 4 | Arco do Cerrado Nordestino: taxa de urbanização, densidade demográfica e número de municípios, segundo o estrato de área plantada

\begin{tabular}{|c|c|c|c|c|c|c|c|}
\hline $\begin{array}{l}\text { ESTATO DE } \\
\text { ÁREA PLANTADA } \\
\text { (HECTARES) }\end{array}$ & $\begin{array}{c}\text { NRO. } \\
\text { MUNICÍPIOS }\end{array}$ & $\begin{array}{c}\text { ÁREA } \\
\text { PLANTADA } \\
\text { TOTAL (HA) }\end{array}$ & $\begin{array}{l}\text { MÉDIA DA AP / } \\
\text { MUNICÍPIO (HA) }\end{array}$ & $\begin{array}{l}\text { POPULAÇÃO } \\
\text { TOTAL (2010) }\end{array}$ & $\begin{array}{c}\text { POPULAÇÃO } \\
\text { TOTAL (\%) }\end{array}$ & $\begin{array}{c}\text { TAXA DE } \\
\text { URBANIZAÇÃO } \\
(2010)\end{array}$ & $\begin{array}{l}\text { DENSID. } \\
\text { DEMOG. } \\
\left(\mathrm{HAB} / \mathrm{KM}^{2}\right)\end{array}$ \\
\hline $\begin{array}{l}\text { Mais de } 100 \\
\text { mil }\end{array}$ & 6 & 889.005 & $148.167,5$ & 362.496 & 34,9 & $79,0 \%$ & 5,1 \\
\hline $\begin{array}{l}\text { Entre } 50 \text { e } 100 \\
\text { mil }\end{array}$ & 3 & 233.520 & $77.840,0$ & 49.882 & 4,8 & $61,9 \%$ & 2,7 \\
\hline $\begin{array}{l}\text { Entre } 20 \text { e } 50 \\
\text { mil }\end{array}$ & 8 & 255.588 & $31.948,5$ & 102.899 & 9,9 & $62,4 \%$ & 2,0 \\
\hline $\begin{array}{l}\text { Entre } 10 \text { e } 20 \\
\text { mil }\end{array}$ & 7 & 96.684 & $13.812,0$ & 78.234 & 7,5 & $47,5 \%$ & 4,0 \\
\hline Até $10 \mathrm{mil}$ & 25 & 89.342 & $3.573,7$ & 443.676 & 42,8 & $50,4 \%$ & 7,1 \\
\hline Total & 49 & 1.564 .139 & $31.921,2$ & 1.037 .187 & 100,0 & $61,9 \%$ & 4,6 \\
\hline
\end{tabular}

Fonte IBGE (Censo Demográfico de 2010 E Agropecuário de 2006) - ElaboraÇão própria.

Segundo os dados acima, não é o fato de ser rural, considerando o predomínio de uma atividade agrícola e a baixa densidade demográfica, que caracteriza as áreas de expansão da fronteira agrícola, mas a existência de um fato urbano relevante. Os 17 municípios situados nos estratos superiores a 20 mil hectares de AP apresentam as maiores taxas de urbanização, acima de $60 \%$. Somente os 07 municípios situados no estrato entre 10 mil e 20 mil hectares de AP apresentam menor taxa de urbanização, inferior a 50\%, mas não têm a menor densidade demográfica média se comparados aos demais. Inclusive porque os 25 municípios situados no estrato até 10 mil hectares de AP, ou seja, com menor área plantada, apresentam densidade demográfica média de 7,1 habitantes por quilômetro quadrado. Quanto maior a área plantada, maior é a taxa de urbanização no agrupamento de 17 municípios acima de 20 mil hectares. Esta relação, entretanto, precisa ainda ser testada para uma base de dados maior e complementada com informações qualitativas de pesquisa de campo.

Os dados preliminares reforçam a hipótese sobre o papel da expansão da fronteira na redefinição do padrão de urbanização brasileiro. Não é a densidade demográfica que define os municípios estudados como rurais, mas o fato de serem agrícolas e urbanos. E são urbanos porque estariam situados nas classes intermediária e superior de população urbana, em cidades acima de 20 mil ou de 50 mil habitantes. São urbanos porque o crescimento de suas áreas plantadas estão levando a uma urbanização prematura da população, decorrente da apropriação do capital no espaço. 
O subespaço regional aqui denominado de Arco do Cerrado Nordestino abriga, portanto, características próprias de um padrão de urbanização que chamamos de periférico por apresentar heterogeneidades espaciais que destoam de padróes de urbanização com base na expansão industrial ou do padrão urbano-industrial da Região Sudeste do Brasil, por exemplo. O padrão periférico de urbanização é disperso, possibilita o surgimento ou é marcado pela presença mais constante de cidades pequenas (abaixo de 20 mil habitantes), é mais agrícola e urbano que apenas rural e concentra ainda boa parte da população urbana em cidades até 50 mil habitantes. Os municípios de Barreiras e Luís Eduardo Magalhães destacam-se no estado da Bahia, o de Bom Jesus e Uruçuí, no estado do Piauí e os de Balsas, Chapadinha e Grajaú, no estado do Maranhão, concentram maior população urbana, pois suas taxas de urbanização variam entre $74 \%$ e $90 \%$.

\section{Há um padrão periférico de urbanização?}

A discussão proposta é sobre o que são e como se estruturam os padrões periféricos de urbanização na América Latina. O caso brasileiro ajuda a pontuar alguns elementos interpretativos que caracterizariam o que se denomina de padrão periférico de urbanização. Isso leva à discussão das características da urbanização em áreas de expansão da fronteira agrícola, refinando a divisão social do trabalho para além da separação tradicional campo-cidade ou rural-urbana e promovendo outros padrões de urbanização, diferentemente do que ocorreu nos países centrais do capitalismo desenvolvido ou no próprio Brasil na fase da industrialização pesada, entre 1956-1980.

Foi sobretudo a baixa incorporação e difusão de progresso técnico na economia brasileira que contribuiu enormemente para consolidar o caráter assimétrico do processo de desenvolvimento, característica básica do que Furtado viria a chamar de subdesenvolvimento. O país ficaria rico, mas injusto. Esse elemento central da sua teoria do subdesenvolvimento pode ser muito bem transposto para o nível espacial, aliás, como fez Milton Santos em seu lúcido trabalho "A urbanização desigual", de 1979, e no seminal "O espaço dividido", de 1973.

Estas duas perspectivas, a de Furtado e Santos, referem-se às capacidades assimétricas que diferenciam os países do centro e da periferia, seja pela via da modernização dos padrões de consumo sem distribuir renda, seja pela via da urbanização estreitamente comprometida com as necessidades da industrialização e sem maiores preocupações com o equilíbrio socioespacial das cidades. $\mathrm{O}$ processo de industrialização e urbanização periférico transformou as cidades brasileiras em pólos de desigualdade. Tal característica estrutural fez com que as cinco grandes regiões brasileiras reproduzissem, em suas próprias fronteiras, as mesmas assimetrias, mimetizando o modelo de desenvolvimento e de urbanização desiguais através do padrão de acumulação concentrador da renda e do padrão de urbanização em dois circuitos, o superior (moderno) e o inferior (empobrecido). 
O geógrafo Milton Santos, no livro A urbanização brasileira, de 1993, já havia chamado a atenção para as diferenças entre população urbana, rural e agrícola, mostrando que a queda relativa da população rural era mais acentuada que o da população agrícola no Brasil. Santos (2009) aponta dois elementos para explicar o fenômeno, um deles é a expansão da fronteira agrícola e o outro as migrações inter-regionais.

O fenômeno não se dá de maneira homogênea, uma vez que são diferentes os graus de desenvolvimento e ocupação prévia das diversas regiões, pois estas são diferentemente alcançadas pela expansão da fronteira agrícola e pelas migrações inter-regionais. (Santos, 2009, p. 34)

São "cidades agrícolas" aquelas que surgem dotadas de um fator urbano próprio e sob o efeito do alcance do processo de expansão da fronteira agropecuária e das migrações entre regiões, transferindo contingentes social e culturalmente diferenciados de populações para subespaços regionais que se caracterizam como verdadeiras plataformas exportadoras de grãos ou carne bovina ou como retaguardas territoriais para a realização da produção agropecuária. São cidades agrícolas no sentido de abrigarem no interior do município ou da hinterlândia modalidades de produção agropecuária, e o fator urbano se manifesta de modo uniforme, como um "implante urbano" para favorecer a logística de escoamento dessa produção. $\mathrm{O}$ espaço rural do município, todavia, perde características naturais e singularidades.

Nos termos do debate europeu, também adotado no Brasil, o rural seria um espaço relacional diferenciado que ocupa um lugar estratégico no processo de desenvolvimento e contempla diversidade e singularidade. Segundo Abramovay (2003),

A ruralidade não é uma etapa do desenvolvimento social a ser superada com o avanço do progresso técnico e da urbanização. Ela é e será cada vez mais um valor para as sociedades contemporâneas. É em torno deste valor e não somente de suas atividades econômicas setoriais que se procuraram aqui as características mais gerais do meio rural: relação com a natureza, regióes não-densamente povoadas e inserção em dinâmicas urbanas. A importância entre nós da agricultura não deve impedir uma definição territorial do desenvolvimento e do meio rural. (Abramovay, 2003, p. 51)

O autor chama a atenção para a imensa diversidade que caracteriza o meio rural, embora existam traços comuns de ruralidade entre regiões. Por esse ângulo, a pobreza rural deixa de ser um problema de insuficiência de renda agropecuária, para ser um fenômeno de múltiplas causas ou multidimensional. Dessa forma, falar em Desenvolvimento Rural, para Abramovay (2003), não é reconhecer o "espaço residual” propício à concentração ou expansão urbana ou ao que ele se credencia a ser normalmente, no máximo, receptor de políticas sociais de combate à pobreza. Para esse autor, Desenvolvimento Rural significa, sobretudo, falar da "capacidade das regióes rurais de preencher determinadas funções necessárias a seus habitantes e também às cidades". Suas conclusões básicas são de que: (1) o Rural deve ser compreendido em suas relações com as cidades, com as regiões metropolitanas e com os pequenos centros em torno dos quais se organiza a vida local; (2) nem toda aglomeração urbana pode ser adequadamente chamada de cidade, pois cabe um importante papel para as 
aglomerações rurais no desenvolvimento territorial; (3) o meio rural não se define pelos traços comuns que encerra, mas pela imensa diversidade que o caracteriza.

Graziano da Silva (2001), por sua vez, considera que o espaço rural, além de diferenciado especificamente pela relação com a terra e mais amplamente com a natureza e o meio ambiente, está profundamente relacionado com aquele espaço que lhe é contíguo, o urbano. Sendo assim, há a proeminência do continnum espacial enquanto uma característica marcante da realidade atual, mesmo que caótica. O continnum espacial não necessariamente integra o rural e o urbano, como diz o autor, mas, pelo menos, cria muitos vínculos entre estas duas frações espaciais. Portanto, a perspectiva de realização social das populações locais que habitam indistintamente os espaços rurais e urbanos é dada pelo acesso, em termos de cidadania, ao que esse continnum espacial venha a oferecer, e, por enquanto, o que oferecem são precárias condições de vida, aos mais pobres especialmente. Para este autor, há um novo rural em plena gestação e isso, a nosso ver, reforça o papel da dimensão urbana no desenvolvimento em vez de enfraquecê-la.

No caso da dimensão urbana, Matos (2005) observa que algumas tendências dos anos de 1970 e 1980 não se confirmaram de todo. A tendência à macrocefalia, a famosa "explosão metropolitana", não se confirmou e nem houve um "esvaziamento" completo do espaço rural conseqüentemente. Pelo contrário, o processo de urbanização, a partir dos anos de 1990, tornou-se disseminado, com tendência mais forte à interiorização do fenômeno urbano em direção às cidades médias e metrópoles em formação, com diminuição no ritmo de crescimento dos grandes centros. $\mathrm{O}$ autor é crítico à utilização da densidade demográfica como um critério decisivo para diferenciar área rural de área urbana, tendo em vista as tendências atuais de maior fragmentação da mancha urbana, especialmente quando se verificam mais casos de conurbação (reunião de cidades) nos últimos anos.

O processo de urbanização no Brasil, de fato, interiorizou-se por amplos espaços regionais sem com isso provocar a desmetropolização (já que as metrópoles seguem, centrais e se reproduzindo); expandiu-se em redes geográficas de diversos tipos unindo cidades muito diversificadas funcionalmente; fez emergir protagonistas de peso no rol das chamadas cidades médias (algumas transformadas em "regiões metropolitanas"); fez surgir uma plêiade de pequenas cidades associadas à pluriatividade em expansão no chamado "novo rural"; deu vazão e ofereceu alternativa espacial ao processo de desconcentração econômica e demográfica das últimas décadas. (Matos, 2005, p. 34)

Com base nos autores supracitados, pode-se dizer que o movimento é mais geral do que se imagina e que a dinâmica em curso caracteriza-se pela maior relação rural-urbana ou a maior articulação urbano-rural, já que há uma tendência ao crescimento de cidades mais agrícolas que rurais, como diria Milton Santos. "Cidades agrícolas" caracterizadas por uma urbanização incompleta ou precária e cada vez mais de aspecto homogêneo, desbotando o rural de sua diversidade e singularidade 
e refletindo um urbano menos continnum do que se esperaria, tornando-se cada vez mais uma retaguarda territorial da produção agrícola ou uma plataforma produtiva e mercantil controlada de fora do espaço regional e nacional.

GRÁFICO 6 | ACNE: Evolução das taxa de urbanização e de ruralização dos municípios selecionados

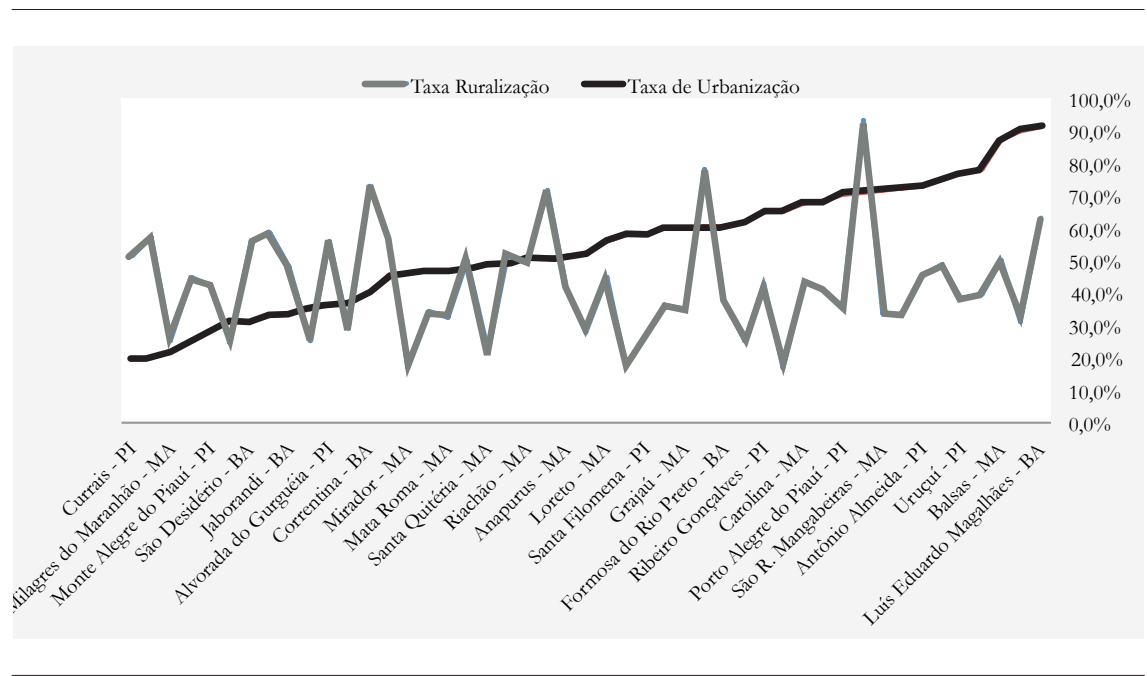

Fonte PAM/IBGE (2010) - ELABorado PELAo AUtor.

No Gráfico 6, observam-se as taxas de urbanização e ruralização ${ }^{4}$ no ACNE. O gráfico mostra a distribuição das taxas, partindo dos municípios com menor taxa de urbanização para os de maior e o comportamento da taxa de ruralização à medida que avança a urbanização. As curvas são bem características no sentido de verificar que os municípios com altos percentuais de áreas mais agrícolas não deixam de ser mais urbanos. Isto é, a taxa de ruralização não deixa de crescer mesmo com o aumento da taxa de urbanização. Quanto mais se ocupam as áreas do município com produção de grãos, mas há movimento de população concentrada nas cidades. $\mathrm{O}$ processo de modernização agrícola, com especialização produtiva, urbaniza mais rápida e precariamente.

Mesmo que se adote um enfoque setorial, falar estritamente da agricultura no Brasil não invalida o aspecto espacial subjacente, ou seja, a relação com o urbano. Isto porque a agricultura brasileira tem caráter itinerante e essa condição lhe dá uma dimensão toda particular, porque é este caráter espacial móvel que, em primeira instância, assegura as condições para o próprio urbano expandir-se, dispersiva ou difusamente, espraiando a rede urbana através de rebentos de cidades, ainda precariamente urbanas, pois o fato urbano, enquanto dinâmica socioespacial específica encontra-se indeterminado.

4 A Taxa de Ruralização é a relação entre a área agrícola total do município e a área geográfica do município em hectares. Não estão incluídas as áreas de pastagens e outras. 
Para se pensar um universo virtual de novas formas urbano-rurais —as que já nasceram e são pouco visíveis e outras mais, pedindo para nascer- é necessário aceitar a complexidade da urbanização contemporânea e abarcar as muitas e diversas situações encontradas nesse processo dito de extensão. Trata-se, desde já, de entender que todo o espaço social está integrado sob a égide do tecido urbano-industrial que inclui também, por certo, formas intensivas de produção do espaço e ocupação do território: cidades, grandes áreas urbanas, áreas industriais, áreas de turismo, extensões metropolitanas e outras mais. (Monte-Mór e Linhares, 2009, p. 157)

No caso da urbanização oriunda do avanço da fronteira agropecuária, as pequenas cidades, por exemplo, jogam um papel importante, devido à maior dispersão territorial que as acomete. Um dos traços mais característicos de boa parte das cidades brasileiras foi terem constituído uma "urbanização frouxa”, ou seja, o conteúdo urbano das cidades está muito longe de expressar aquilo que Lefebvre (2001) chamou de "direito à vida urbana", pouco importando se seu conteúdo tende a ser "mais rural" ou "mais urbano", ou se seu tamanho é grande ou pequeno. De um modo geral, as cidades que foram "plantadas" no território brasileiro tiveram diferentes motivações, mas no caso do espaço sub-regional denominado aqui de Arco do Cerrado Nordestino, tanto as pequenas quanto as maiores cidades agrícolas ali situadas, o urbano funciona como um "implante", para servir de base de serviços da agricultura de exportação principalmente.

Torna-se premente, portanto, entender o que são e como se estruturam os padrões periféricos de urbanização na América Latina em face dessa nova realidade dos circuitos mercantis. Por mais que cada um dos países latino-americanos possua diferenças de ordem política e cultural marcantes, do ponto de vista social, econômico e, inclusive, ambiental, são os traços comuns à dinâmica urbana neles impressos que levam a reproduzir padrões periféricos de urbanização, os quais se caracterizam por fortes heterogeneidades socioespaciais. Daí a premência em se ampliar o debate, seja no que se refere ao processo de urbanização como um todo ou ao modo como ele vem ocorrendo, especialmente, a partir da expansão da fronteira agrícola, agropecuária ou mineral nos diferentes países.

\section{Considerações finais}

Neste artigo, discorremos sobre a relação rural-urbana como faces igualmente importantes do processo de urbanização tardia no Brasil. Considerou-se tanto o rural quanto o urbano como processos de formação socioespaciais decorrentes de diferentes estágios de "urbanização tardia”. Aqui, urbano e rural não são entendidos como duas faces de uma mesma moeda, o modelo urbano-industrial, mas como um mesmo processo (apropriação privada do espaço) de urbanização tardia. A ênfase relacional chama a atenção para o fato de não se atribuir ao segmento urbano, isoladamente, as determinações do processo de urbanização. O "jogo de escalas" espaciais influencia a dinâmica urbana também em sua face rural. A visão vai além da cidade e seu entorno, preocupa-se com a apropriação territorial. Na verdade, 
não é a definição de um limite separando o urbano do rural que está em questão, mas o limite que o urbano encontra no rural. $\mathrm{O}$ limite da urbanização extensiva. $\mathrm{O}$ que se torna urbano não corresponde necessariamente ao processo de urbanização em sentido pleno. A urbanização incompleta ou inconclusa e a cidade dispersa ou difusa são mais bem entendidas pela interação rural-urbana.

Países de origem colonial realizaram uma transição campo-cidade ou rural-urbana incompleta ou fraca, nos dois sentidos, o campo e o rural tiveram e continuam a ter um peso importante, seja em termos produtivos e socioespaciais e a cidade e o urbano mais abrigaram fluxos populacionais, crescendo o tecido urbano sem oferecer melhores condições de vida urbana, via maior inclusão social. Se, do ponto de vista demográfico, o rural "desaparece", do ponto de vista socioeconômico-espacial, o rural ressurge. Esse espaço rural ressurgente é o espaço que, sob o comando do capital, ressignifica o próprio espaço urbano como relação socioespacial. O presente artigo colocou em evidência alguns elementos associados à dinâmica urbanoregional na fronteira agrícola como uma característica recente de um país cuja agricultura se moderniza. Desse modo, não se trata apenas de herança colonial, mas de um padrão de urbanização que se forja e define em suas características específicas.

Entre os cientistas sociais brasileiros que estudam o rural, como Veiga, Abramovay, Graziano da Silva, Nazareth Wanderley, entre outros, há certo consenso de que a dicotomia campo-cidade foi superada e que a visão setorial e os limites municipais escondem mais do que mostram, seja para enfatizar as potencialidades do rural ou os limites da sua frágil ou ausente regulação. Graziano da Silva (2002) mostra como novos agentes (os neorurais) surgem do crescimento das atividades rurais não agrícolas e Veiga (2001), por seu turno, chama atenção para as características mais rurais que urbanas da maioria das cidades brasileiras, argumentando que o Brasil é mais rural do que se imagina. Já Milton Santos (1982) chamou de "cidades locais" aquelas que exercem um padrão primário de consumo, respondendo a necessidades imediatas da população e cumprindo um papel importante no mercado urbano intra-regional. Ao contrário do que recomendou Lewis Munford em seu livro clássico, "A cidade na história", se quisermos identificar as cidades, devemos seguir sua trilha para frente e não para traz, isto é, identificar suas novas fontes de dinamismo econômico, social e espacial e analisar as implicações. Isto vale para as cidades do Arco do Cerrado Nordestino, posto que, sem identificar suas novas fontes de dinamismo e tratando-as isoladamente, não se poderão antecipar as consequências socioespacialmente insustentáveis ali forjadas.

O caráter itinerante da agricultura nacional influiu nos fatores de diferenciação, desequilíbrios e desigualdades regionais no Brasil. Do ponto de vista da análise regional, identifica-se no fenômeno da itinerância na agricultura brasileira um dos elementos motrizes das transformações nos espaços rurais ao longo do tempo, com repercussão no processo de urbanização. A urbanização periférica tem no fenômeno da "itinerância territorial", portanto, uma de suas principais características. Cano (2002), nos Ensaios sobre a formação econômica regional do Brasil, já havia chamado a atenção para esse aspecto da formação econômica nacional. O termo 
itinerância expressa a relação territorial da economia agro-exportadora moderna com a dinâmica agrária brasileira. A itinerância está imersa numa relação de "expropriação" espacial da base de recursos naturais e deriva do sentido de modernidade conservadora do desenvolvimento histórico brasileiro. Trata-se do processo de apropriação privada do território nacional, que deu o sentido à formação de um espaço regional com flagrantes níveis de desigualdades sociais e de degradação ambiental. Este processo foi marcado por uma concentração econômico-espacial que incentivou um crescimento urbano acelerado em detrimento do desenvolvimento espacialmente equilibrado entre o rural e o urbano.

As áreas não metropolitanas podem reproduzir ou mimetizar o processo de urbanização das áreas metropolitanas, mas o que chama atenção é o aumento da desigualdade e heterogeneidade socioespacial na urbanização periférica. Cobos (2008) tem chamado a atenção para o fato que o desenvolvimento desigual produziu, nos últimos anos na América Latina, da pequena cidade à extensa cidaderegião múltiplas formas urbanas que se combinam complexamente, com tamanhos populacionais e estruturas econômico-sociais muito distintas (Cobos, 2008, pp. 151-152). Embora Cobos discuta esse problema ao analisar as metrópoles periféricas, aqui neste artigo tentou-se mostrar que o processo é mais amplo e está vinculado também ao avanço da fronteira agrícola e, por conseguinte, está presente em áreas não metropolitanas, todavia, com novas determinações: o controle do espaço pelo capital acontece de fora do território e não se vincula, como no passado, à industrialização, mas ao circuito mercantil das commodities e, especialmente, com a ascensão da China.

O período 1990-2010 é um período em que o padrão de urbanização brasileiro, produto ou resultado da expansão da fronteira agrícola, caracterizou-se pelo aprofundamento das heterogeneidades socioespacias que passaram a se refletir na dinâmica urbana específica dos espaços inter e intra-regionais. É importante entender a urbanização como uma dinâmica socioespacial engendrada por determinações mais amplas da economia capitalista, cristalizadas tanto em padrões produtivos como de consumo. Uma agenda de pesquisa voltada para a caracterização de padrões periféricos de urbanização na América Latina exige, naturalmente, um esforço coletivo e capacidade de cooperação, para que avancem as análises das suas particularidades em diferentes processos de expansão da fronteira agropecuária e mineral: mapear padrões de consumo das cidades, diferenciação social, impactos socioambientais específicos, migrações inter-regionais etc. Espera-se que estas reflexões ajudem a aprofundar o tema da urbanização e da relação rural-urbana nesta região. 


\section{Anexo A}

FIGURA 1 | BRASIL: Municípios Plantadores de Soja acima de 1000 hectares (2009)

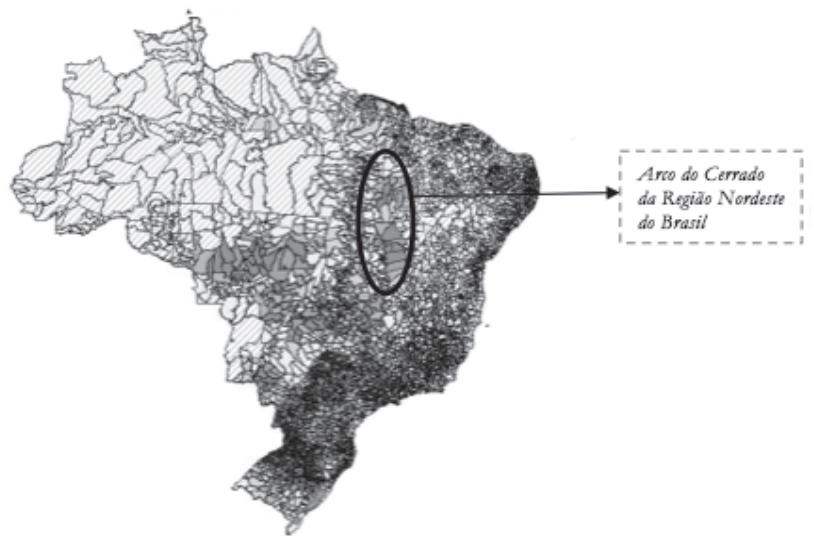

BRASIL: Área Plantada com Soja (2009)

\begin{tabular}{cccc}
\hline Cor $\quad$ Estrato de Área (ha) & $\begin{array}{c}\text { Municípios } \\
\text { Brasil }\end{array}$ & $\begin{array}{c}\text { Municípios } \\
\text { Nordeste }\end{array}$ \\
\hline 1.000 a 10.000 & 697 & 23 \\
10.001 a 20.000 & 213 & 10 \\
20.001 a 50.000 & 169 & 6 \\
50.001 a 100.000 & 54 & 5 \\
Acima de 100.000 & 32 & 5 \\
\hline
\end{tabular}

Fonte IBGE - Produção Agrícola Municipal. 


\section{Anexo B}

\section{FIGURA 2 | BAHIA (IBGE)}

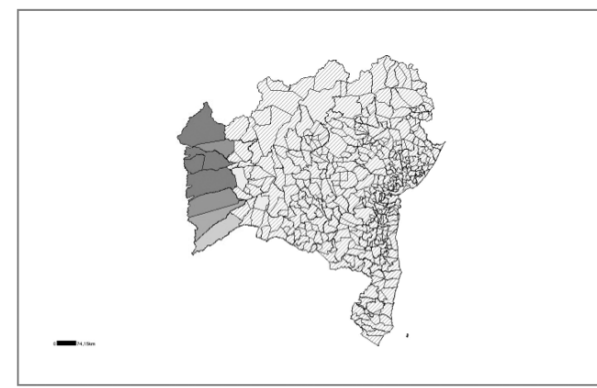

BAHIA: Área Plantada com Soja (2009)

\begin{tabular}{ccc}
\hline Cor & Estrato de Área (ha) & Municípios \\
\hline 1.000 a 10.000 & 2 \\
10.001 a 20.000 & 1 \\
20.001 a 50.000 & 1 \\
50.001 a 100.000 & 2 \\
Acima de 100.000 & 4 \\
\hline
\end{tabular}

Fonte IBGE - Produção Agrícola Municipal.

FIGURA 3 | MARANHÃO (IBGE)

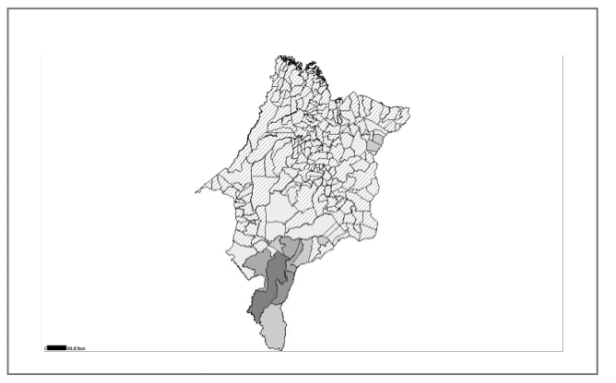

MARANHÃO: Área Plantada com Soja (2009)

\begin{tabular}{ccc}
\hline Cor & Estrato de Área (ha) & Municípios \\
\hline 1.000 a 10.000 & 14 \\
10.001 a 20.000 & 6 \\
20.001 a 50.000 & 3 \\
50.001 a 100.000 & 1 \\
Acima de 100.000 & 1 \\
\hline
\end{tabular}

Fonte IBGE - Produção Agrícola Municipal.

FIGURA 4 | PIAUÍ (IBGE)

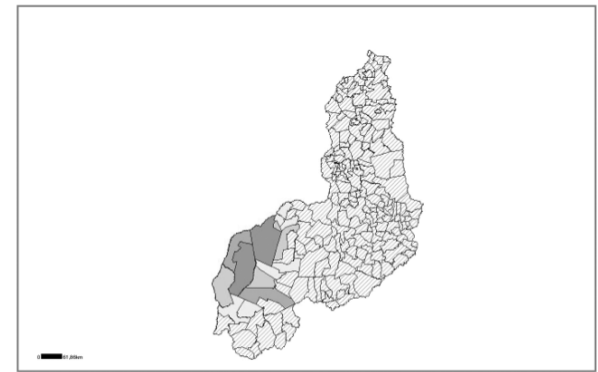

PIAUÍ: Área Plantada com Soja (2009)

\begin{tabular}{ccc}
\hline Cor & Estrato de Área (ha) & Municípios \\
\hline 1.000 a 10.000 & 7 \\
10.001 a 20.000 & 3 \\
20.001 a 50.000 & 2 \\
50.001 a 100.000 & 2 \\
Acima de 100.000 & 0
\end{tabular}

Fonte IBGE - Produção Agrícola Municipal. 


\section{Referências bibliográficas}

Abramovay, R. (2003). Funções e medidas da ruralidade no desenvolvimento contemporâneo. En R. Abramovay, O futuro das regióes rurais (pp.17-56). Porto Alegre, RS: Editora da Universidade Federal do Rio Grande do Sul (UFRGS).

Balsadi, Otávio. (2008). O mercado de trabalho assalariado na agricultura brasileira e suas diferenciações regionais no período 1992-2004. São Paulo: Editora Hucitec (Humanismo, Ciência e Tecnologia).

Cano, W. (2002). Ensaios sobre a formação econômica regional do Brasil. Campinas, SP: Ed. Universidade Estadual de Campinas (Unicamp).

Cano, W. (2008). Desconcentração produtiva regional do Brasil 1979-2005. São Paulo: Editora Universidade Estadual Paulista Júlio de Mesquita Filho (Unesp).

Cobos, E. P. (1989). Acumulación de capital y estructura territorial en América Latina. En M. Lungo (Comp.), Lo urbano: Teoría y métodos (pp. 31-67). San José, Costa Rica: Secretaria General Consejo Superior Universitario Centroamericano (CSUCA)/Editorial Universitaria Centroamericana.

Cobos, E. P. (2008). Presente y futuro de las metrópolis de América Latina. Territorios (Bogotá), 1819, 147-181.

Cobos, E. P. (2010). Teorias y políticas urbanas: libre mercado mundial, o construcción regional? Revista Brasileira de Estudos Urbanos e Regionais, 12(2), 9-21.

Delgado, G. C. (2001). Expansão e modernização do setor agropecuário no pós-guerra: um estudo de reflexão agrária. Estudos Avançado (Instituto de Estudos Avançados/USP, São Paulo), 15(43), 157-172.

Graziano da Silva, J. (2001). Quem precisa de uma estratégia de desenvolvimento? En José Graziano da Silva, Jean Marc e Bianchini debatem O Brasil Rural precisa de uma estratégia de desenvolvimento (pp. 5-52) Brasília, DF: Brasília: Ministério do Desenvolvimento Agrário (MDA)/ Conselho Nacional de Desenvolvimento Rural Sustentável (CNDRS)/Núcleo de Estudos Agrários e Desenvolvimento Rural (NEAD).

Instituto Brasileiro de Geografia e Estatística (IBGE). (2006). Censo Agropecuário. Rio de Janeiro (pp. 1-777). (Livro com CD).

Instituto Brasileiro de Geografia e Estatística (IBGE). (2010). Censo Demográfico. Brasil. Rio de Janeiro. Disponível em: http://www.censo2010.ibge.gov.br/.

Instituto Brasileiro de Geografia e Estatística (IBGE). (2010). Produção Agrícola Municipal - culturas temporárias e permanentes, v. 37: Brasil (pp. 1-91). Rio de Janeiro. (Livro com CD).

Lefebvre, H. (2001). O direito à cidade. (Tradução: Rubens Eduardo Frias). São Paulo: Centauro.

Matos, R. (2005). Das grandes divisões do Brasil à ideia do urbano em rede tripartite. En R. Matos (Org.), Espacialidades em rede: população, urbanização e migração no Brasil contemporâneo (pp.17-56). Belo Horizonte, MG: C/Arte.

Monteiro Neto, A. (2005). Desenvolvimento regional em crise: políticas econômicas liberais e restrições à intervenção estatal no Brasil dos anos 90. Tese (Doutorado), Instituto de Economia da Universidade Estadual de Campinas. Campinas, SP.

Monte-Mór, R. L. \& Linhares, L. (2009). Urbanização extensiva: expressões no Brasil. En N. G. Reis (Org.), Sobre dispersão urbana. São Paulo: Via das Artes. 
Oliveira, Luiz G. (2002). Alguns aspectos da guerra fiscal. En A. Kon (Org.), Unidade e fragmentação: a questão regional no Brasil (pp. 197-219). São Paulo: Editora Perspectiva.

Santos, M. (1982). A urbanização desigual: a especificidade do fenômeno urbano em países subdesenvolvidos. Petrópolis, RJ: Vozes.

Santos, M. (2009) [1993]. A urbanização brasileira (5 ed., 2a reimpr.). São Paulo: Editora da USP.

Santos, M. (2010). Ensaios sobre a urbanização latino-americana. (2a ed.). São Paulo: Editora da Universidade de São Paulo (EDUSP).

Souza, L. E. S. \& Fonseca, P. C. D. (Orgs.). (2009). O processo de substituição de importações. São Paulo: LCTE Editora.

Veiga, J. E. (2001). Desenvolvimento territorial no Brasil: do entulho varguista ao zoneamento ecológico-econômico. Babia Análise \& Dados (Salvador, BA), 10(04), 193-206. 
